\title{
WSZĘDZIE DOBRZE, ALE W DOMU NAJLEPIEJ. ANALIZA DECYZJI DOTYCZĄCYCH KONTYNUACJI NAUKI NA STUDIACH DRUGIEGO STOPNIA NA PODSTAWIE DANYCH REJESTROWYCH UNIWERSYTETU WARSZAWSKIEGO
}

\begin{abstract}
Zając Tomasz, Komendant-Brodowska Agata, Wszędzie dobrze, ale w domu najlepiej. Analiza decyzji dotyczacych kontynuacji nauki na studiach drugiego stopnia na podstawie danych rejestrowych Uniwersytetu Warszawskiego [There is no Place Like Home. Analysis of the Decisions of First-Degree Graduates Concerning Continuing Education Based on Registers of the University of Warsaw]. Studia Edukacyjne nr 42, 2016, Poznań 2016, pp. 309-332. Adam Mickiewicz University Press. ISSN 1233-6688. DOI: $10.14746 /$ se.2016.42.19
\end{abstract}

The aim of the paper is to analyse decisions of first degree graduates concerning continuation of their education on second-degree programmes. One of the changes introduced by the Bologna process was a division of university programmes for the first-degree (bachelor's degree) and seconddegree (master's degree) programmes. As a result, a new educational threshold has appeared in the course of higher education and at that threshold students decide whether to continue education and if so, which university and programme to choose. All choices involve various costs and benefits, both to be experienced immediately, as well as those that students plan to achieve or incur in the future. The article presents data on the decisions regarding the continuation of studies in the context of the assumptions of rational choice theory: methodological individualism and rationality of actors. The analysed data come from registers of the University of Warsaw. The most common decision of first-degree graduates at the University is not to change anything: either the programme or mode of study. This result will be explained in the context of assumptions about the preferences of the students.

Key words: second degree studies, sociology of education, educational choices, rational choice theory, register data analysis

\section{Wprowadzenie}

Podział studiów na pierwszego i drugiego stopnia, kończących się odpowiednio uzyskaniem dyplomu licencjata i magistra, wprowadzony 
w wyniku procesu bolońskiego, daje studentom szansę na podjęcie różnych decyzji dotyczących studiowania po ukończeniu studiów pierwszego stopnia. Młodzi ludzie z dyplomem licencjata mają cały szereg możliwości do wyboru: mogą przede wszystkim zdecydować się na zakończenie edukacji na tym etapie, przerwać naukę z zamiarem powrotu w późniejszym czasie, kontynuować edukację $\mathrm{w}$ ramach studiów drugiego stopnia. Nie ma przy tym obowiązku realizacji nauki na tym samym kierunku. Osoby pragnące ją kontynuować mogą zmienić uczelnię, kierunek oraz tryb studiów. Formalnie, absolwent studiów pierwszego stopnia może ubiegać się o przyjęcie na dowolne studia drugiego stopnia, jednak musi spełnić wymagania stawiane przez jednostkę dydaktyczną, w której zamierza podjąć studia, np. zdać odpowiednie egzaminy wstępne. Warto podkreślić, że problem wyboru dalszej ścieżki kształcenia dotyczy znacznej liczby osób. Na przykład, w Polsce w roku akademickim 2012/2013 dyplom studiów pierwszego stopnia uzyskało 256 tysięcy osób ${ }^{1}$. Ich wybory są istotne w kontekście dyskusji o budowaniu kapitału ludzkiego, efektywności polityki edukacyjnej, nierówności edukacyjnych, czy też mobilności edukacyjnej².

Celem niniejszego artykułu jest analiza decyzji absolwentów studiów licencjackich dotyczących kontynuacji nauki na drugim stopniu studiów. Została ona przeprowadzona na podstawie danych pochodzących z rejestrów administracyjnych Uniwersytetu Warszawskiego. Na przykładzie tej uczelni prześledzimy decyzje absolwentów, opierając się przy tym na założeniach teorii racjonalnego wyboru. Analiza zachowań absolwentów studiów pierwszego stopnia posłuży do odpowiedzi na następujące pytania:

- Jaka część absolwentów studiów pierwszego stopnia na UW bierze udział w rekrutacji na studia II stopnia na UW?

- Jaka część ubiegających się o przyjęcie na studia chciała rozpocząć studia w tej samej jednostce dydaktycznej, a jaka część zmienia jednostkę?

- Jaka część absolwentów zmienia tryb studiów?

- Czy osoby pragnące podjąć studia na UW zostają zakwalifikowane i przyjęte na studia?

Odpowiadając na każde powyższe pytanie przeanalizujemy, jak zmieniały się decyzje absolwentów w latach 2010-2014.

${ }^{1}$ GUS, Szkoty wyższe i ich finanse w 2013 roku, Warszawa 2014.

2 M.in. S. Reichert, C. Tauch, Trends 2003. Progress towards the European Higher Education Area, http://www.eua.be/eua/jsp/en/upload/Trends2003final.1065011164859.pdf [dostęp: 10.09.2012]. 


\section{Perspektywa teoretyczna: decyzje absolwentów w kontekście teorii racjonalnego wyboru}

Teoria racjonalnego wyboru opiera się na dwóch głównych założeniach: indywidualizmu metodologicznego i racjonalności działania ${ }^{3}$. Pierwsze z tych założeń oznacza konieczność odwołania się do decyzji jednostek $\mathrm{w}$ analizie zjawisk społecznych ${ }^{4}$. Przyjmujemy więc, że w analizie problemu o charakterze społecznym konieczne jest odwołanie się do decyzji indywidualnych, które z jednej strony zależą od kontekstu społecznego, natomiast $z$ drugiej - prowadzą do pewnych rezultatów na poziomie społecznym ${ }^{5}$.

Przyjmujemy również, że aktorzy zachowują się racjonalnié ${ }^{6}$. Oceniając dostępne alternatywy (opcje) przed wybraniem najkorzystniejszego dla siebie rozwiązania - maksymalizującego ich użyteczność - dokonują kalkulacji kosztów i korzyści. Należy przy tym zastrzec, że sposób w jaki ludzie postrzegają koszty i korzyści daleki jest od ich czysto pieniężnego wymiaru. W przypadku decyzji edukacyjnych nie zawsze pod uwagę brane są przyszłe zarobki, na które można liczyć po zakończeniu edukacji. Niejednokrotnie ważniejsze są: rozwój intelektualny, zdobyta wiedza, czy prestiż związany $\mathrm{z}$ osiągnięciem pewnego poziomu wykształcenia, a także zgodność z zainteresowaniami ucznia lub studenta. Co więcej, wszystkie te decyzje zasadzają się na wiedzy, jaką jednostki dysponują i są uzależnione od zasobów, jakimi one rozporządzają7 .

${ }^{3}$ M.in. G. Lissowski, Teoria racjonalnego wyboru, [w:] Encyklopedia socjologii, Wydanie 4, Warszawa 2002, s. 194-198.

${ }^{4}$ J.S. Coleman, Social theory, social research, and a theory of action, American Journal of Sociology, 1986, 91, 6, s. 1309-1335.

${ }^{5}$ A. Komendant-Brodowska, A. Baczko-Dombi, Lokalne uwarunkowania decyzji edukacyjnych w perspektywie teorii racjonalnego wyboru. Koncepcja teoretyczno-metodologiczna, Analizy IBE, 2015, 4.

${ }^{6}$ Wyjaśnienia może wymagać założenie o racjonalności, tym bardziej że $\mathrm{w}$ języku polskim słowo to ma mocny, wartościujący wydźwięk, chociażby poprzez odróżnienie zachowań racjonalnych od tych emocjonalnych. W teorii racjonalnego wyboru założenie to nie ma nic wspólnego z wartościowaniem. „Racjonalność to tutaj w zasadzie tyle co działanie nastawione na realizację celu, dążenie do osiągnięcia go przez stosowanie najlepiej do tego dobranych środków" (J. Haman, Gry wokót nas. Socjolog i teoria gier, Warszawa 2014, s. 72). Zakładamy zatem, że aktorzy „dokonują celowych wyborów w oparciu o swoje preferencje (...). Zakłada się, że jednostka jest w stanie uszeregować alternatywy od najlepszej do najgorszej", a także że aktorzy „wybierają w zgodzie z tym, co jest dla nich najlepsze ze względu na ich indywidualne preferencje lub gusta" (D. Lalman, J. Oppenheimer, P. Świstak, Formalna teoria wyboru racjonalnego. Kumulatywne nauki polityczne, Studia Socjologiczne, 1994, 3-4(134-135), s. 19-20). Zakłada się jedynie, że aby uznać preferencje za racjonalne, muszą one spełniać warunki spójności, zwrotności i przechodniości (G. Lissowski, Zasady sprawiedliwego podziatu dóbr, Warszawa 2008, s. 57).

7 Takie podejście do decyzji edukacyjnych szerzej opisane jest w: A. KomendantBrodowska, A. Baczko-Dombi, Lokalne uwarunkowania decyzji edukacyjnych, natomiast przykład 
Analiza oparta na założeniach teorii racjonalnego wyboru umożliwia wyjście poza prosty opis obserwowanych zachowań. Uzyskane wyniki pozwalają na próbę - na podstawie przyjętych założeń i wiedzy na temat kontekstu podejmowanych decyzji - odtworzenia procesu i postaw, które doprowadziły do rezultatu na poziomie makro. Badając wybory dokonywane przez absolwentów, będziemy starać się na odtworzenie procesu podejmowania decyzji i wyciągnięcie wniosków na temat czynników mogących doprowadzić do danego rezultatu, analizując przede wszystkim możliwe koszty i korzyści, jakie mogą wiązać się $\mathrm{z}$ wybieranymi przez absolwentów opcjami.

Z punktu widzenia wnioskowania o postawach absolwentów studiów pierwszego stopnia na podstawie ich decyzji, bardzo istotna jest obserwacja, że na studiach drugiego stopnia konkurencja między kandydatami jest niewielka. Na taki stan rzeczy wpływają, po pierwsze, procesy demograficzne i zmniejszająca się w ostatnich latach liczba studentów ${ }^{8}$. Drugim czynnikiem prowadzącym do tego stanu rzeczy jest to, że niemała część osób rozpoczynających naukę na studiach pierwszego stopnia nie kończy studiów, a liczba miejsc oferowanych na studiach drugiego stopnia często jest podobna do liczby miejsc oferowanych na pierwszym stopniu. Niewielka konkurencja lub jej brak upraszcza analizę. Na studiach pierwszego stopnia i jednolitych magisterskich, na które liczba chętnych przewyższa liczbę miejsc, można obserwować zachowania autoselekcyjne. Kandydaci niekoniecznie wybierają kierunki najbardziej przez siebie preferowane ${ }^{9}$. Na studiach II stopnia podobne zachowania strategiczne nie są konieczne. Można zatem przyjąć, że wybory dokonywane przez osoby ubiegające się o przyjęcie na studia II stopnia, w większym stopniu niż wybory kandydatów na studia I stopnia, odzwierciedlają preferencje kandydatów na zbiorze kierunków studiów.

\section{Podejście metodologiczne i źródła danych}

Zgodnie z założeniem metodologicznego indywidualizmu, jakkolwiek interesuje nas skala zjawisk i trendy na poziomie makro, do ich rozpoznania

modelu opierającego się na teorii racjonalnego wyboru dla decyzji edukacyjnych w: R. Breen, J.H. Goldthorpe, Wyjaśnianie zróżnicowań edukacyjnych: w kierunku formalnej teorii racjonalnego dziatania, [w:] O socjologii. Integracja badań i teorii, red. J.H. Goldthorpe, Warszawa 2012.

${ }^{8}$ M.in. IBE, Raport o stanie edukacji 2012. Licza się efekty, Warszawa 2012; A. Baczko-Dombi, T. Żółtak, Edukacja, [w:] Wspótczesne społeczeństwo polskie. Podręcznik akademicki, red. A. Giza, M. Sikorska, Warszawa 2012.

9 T. Zając, Jak kandydaci staraja się dostać na studia? Analiza strategii kandydatów na wybrane kierunki studiów na Uniwersytecie Warszawskim, Decyzje, 2011, 16, s. 73-104. 
i zrozumienia potrzebne jest jednak odwołanie się do tego, co dzieje się na poziomie jednostek. Do analizy zachowań absolwentów wykorzystaliśmy indywidualne dane rejestrowe zgromadzone w Uniwersyteckim Systemie Obsługi Studiów (USOS) oraz Internetowej Rejestracji Kandydatów (IRK). Podstawową zaletą wykorzystania danych administracyjnych jest możliwość prowadzenia badania całej populacji, a także analiz na wąskich podpopulacjach populacji, co dla socjologa jest nie do przecenienia, tym bardziej w dobie spadających stóp realizacji badań sondażowych. Ponadto, badania tego rodzaju pozwalają na śledzenie dynamiki zjawisk, przy czym dostrzegalne mogą być nawet trendy o na tyle niedużej skali, że w przypadku badań sondażowych można by ich nie dostrzec, a co najmniej mieć wątpliwości co do istotności różnic między kolejnymi punktami w czasie. Nie sposób też nie wspomnieć, że badania na podstawie rejestrów mogą być prowadzone przy stosunkowo niewielkich kosztach ${ }^{10}$.

Z rejestrów USOS zostały wyeksportowane listy dyplomów z kolejnych lat. Jednostką obserwacji w analizie jest zatem nie tyle absolwent, co absolwent kończący konkretny program studiów. Jeśli student uzyskał więcej niż jeden dyplom, to $\mathrm{w}$ zbiorze występuje kilkakrotnie. Takie sytuacje należą jednak do rzadkości - jedynie 3,6\% badanych uzyskało więcej niż jeden dyplom. Dlatego, dla uproszczenia w dalszej części artykułu będziemy mówić o absolwentach, a nie dyplomach. Wraz z informacjami o uzyskaniu dyplomu eksportowane były dane na temat kierunku studiów, jednostki dydaktycznej, daty uzyskania dyplomu oraz uzyskanych ocen. W celu zbadania, którzy absolwenci zdecydowali się na kontynuację studiów na UW, na jakim kierunku i w jakim trybie, wykorzystane zostały indywidualne dane pochodzące z systemu IRK. Na ich podstawie możliwe jest określenie, na jakie kierunki studiów i z jakim skutkiem próbowali się dostać poszczególni absolwenci. Dane z obydwu rejestrów zostały wyeksportowane w październiku 2014 roku.

Wyeksportowane dane zawierały dane dotyczące liczącej 22699 obserwacji populacji absolwentów UW z lat 2010-2014, którzy łącznie uzyskali 23555 dyplomów. Największa liczba dyplomów przypada na 2012 rok 4 988, natomiast najniższa na 2014 rok - 4 262, co wynika po części z faktu, że nie zostały uwzględnione dyplomy $z$ listopada i grudnia roku 2014. Analiza dotyczy więc ogółu absolwentów największej uczelni w kraju, na której obecnie studiuje 44700 osób.

10 M.in. M. Jasiński, Dokładniej, rzetelniej, taniej. Badania oparte na rejestrach publicznych jako szansa dla badań społecznych w Polsce, Studia Socjologiczne, 2015, 1(216); A. Wallgren, W. Britt, Register-based Statistics. Administrative Data for Statistical Purposes, West Sussex 2007. 


\section{Absolwenci UW - opis badanej zbiorowości}

Poniżej przedstawimy, istotne z punktu widzenia dalszych analiz, cechy charakteryzujące populację objętą badaniem. Wśród badanych absolwentów dominują osoby, które ukończyły studia stacjonarne. Dyplomy studiów stacjonarnych wśród ogółu dyplomów stanowią od 72\% w roku 2010 do 80\% w roku 2014. Niewielka liczba dyplomów studiów niestacjonarnych wynika z dwóch powodów. Po pierwsze, na studiach stacjonarnych oferowanych jest najwięcej miejsc i cieszą się one największym zainteresowaniem kandydatów. Po drugie, na studiach stacjonarnych wyższy jest odsetek osób uzyskujących dyplom ${ }^{11}$.

Tabela 1

Informacje na temat dyplomów w kolejnych latach

\begin{tabular}{|c|c|c|c|c|}
\hline \multirow{2}{*}{ Rok } & \multirow{2}{*}{$\begin{array}{c}\text { Liczba } \\
\text { dyplomów }\end{array}$} & stacjonarne & $\begin{array}{c}\text { Tryb ukończonych studiów } \\
\text { niestacjonarne } \\
\text { wieczorowe }\end{array}$ & $\begin{array}{c}\text { niestacjonarne } \\
\text { zaoczne }\end{array}$ \\
\hline $\mathbf{2 0 1 0}$ & 4562 & $72 \%$ & $14 \%$ & $14 \%$ \\
\hline $\mathbf{2 0 1 1}$ & 4770 & $74 \%$ & $15 \%$ & $11 \%$ \\
$\mathbf{2 0 1 2}$ & 4988 & $73 \%$ & $15 \%$ & $11 \%$ \\
$\mathbf{2 0 1 3}$ & 4973 & $77 \%$ & $12 \%$ & $11 \%$ \\
$\mathbf{2 0 1 4}$ & 4262 & $80 \%$ & $10 \%$ & $10 \%$ \\
\hline
\end{tabular}

Czynnikiem wpływającym na możliwości kontynuacji studiów jest termin obrony. Obrona może nastąpić po zamknięciu rekrutacji na interesujące absolwenta kierunki studiów. Pierwsza tura naboru na studia drugiego stopnia ma miejsce w lipcu. Na większości kierunków rekrutacja kończy się przed październikiem. Osoby, które uzyskały dyplom później niż we wrześniu stanowią około jednej dziesiątej absolwentów z kolejnych lat. Specyficzną grupę stanowią także osoby, które dyplom uzyskały na początku roku. Mogą to być studenci, którzy wcześniej spełniali wszystkie wymagania na swoim programie studiów i dlatego mogą bronić pracę dyplomową kilka miesięcy przed terminem. Bardziej prawdopodobne wydaje się jednak, że są to osoby, które powinny obronić prace dyplomowe w poprzednim roku.

${ }^{11}$ M. Bożykowski i in., Ścieżki edukacyjne i zawodowe absolwentów Uniwersytetu Warszawskiego, Edukacja, 2014, 3(128), s. 5-21. 
Tabela 2

Informacje na temat terminu uzyskania dyplomu w kolejnych latach

\begin{tabular}{|c|c|c|c|c|c|}
\hline \multirow{2}{*}{ Rok } & \multirow{2}{*}{$\begin{array}{c}\text { Liczba } \\
\text { dyplomów }\end{array}$} & \multicolumn{4}{|c|}{ Miesiąc uzyskania dyplomu } \\
\hline & & I-III & IV-VI & VII-IX & X-XII \\
\hline 2010 & 4562 & $2 \%$ & $32 \%$ & $57 \%$ & $9 \%$ \\
\hline 2011 & 4770 & $3 \%$ & $31 \%$ & $57 \%$ & $9 \%$ \\
\hline 2012 & 4988 & $3 \%$ & $24 \%$ & $63 \%$ & $11 \%$ \\
\hline 2013 & 4973 & $4 \%$ & $20 \%$ & $67 \%$ & $10 \%$ \\
\hline 2014 & 4262 & $5 \%$ & $17 \%$ & $76 \%$ & $2 \%$ \\
\hline
\end{tabular}

Przypuszczenia te potwierdza analiza wyników na studiach w zależności od terminu obrony dyplomu. Osoby, które zdobyły dyplom w terminie (od IV do IX) osiągają wyraźnie lepsze wyniki na studiach niż te, które uzyskały dyplom w terminach późniejszych (tab. 3). Może to wynikać nie tylko $\mathrm{z}$ różnic $\mathrm{w}$ kompetencjach, ale także $\mathrm{z}$ poziomu zaangażowania $\mathrm{w}$ studiowanie.

Tabela 3

Ogólny wynik studiów mierzony za pomocą średniej ocen ze studiów a termin obrony dyplomu

\begin{tabular}{|c|c|c|c|c|}
\hline \multirow{2}{*}{ Rok } & \multicolumn{4}{|c|}{ Miesiąc uzyskania dyplomu } \\
\cline { 2 - 5 } & I-III & IV-VI & VII-IX & X-XII \\
\hline 2010 & 3,99 & 4,31 & 4,17 & 3,94 \\
\hline 2011 & 3,91 & 4,29 & 4,17 & 3,92 \\
\hline 2012 & 3,95 & 4,29 & 4,17 & 3,91 \\
\hline 2013 & 3,95 & 4,24 & 4,20 & 3,96 \\
\hline 2014 & 3,98 & 4,27 & 4,19 & 3,99 \\
\hline
\end{tabular}

Ze względu na odmienność sytuacji osób kończących studia w poszczególnych kwartałach, analizy dotyczące kontynuacji studiów prowadzone będą osobno dla każdego kwartału. Warto jednak podkreślić, że osoby uzyskujące dyplom w terminie (II i III kwartał) stanowią dla poszczególnych roczników od $86 \%$ do $93 \%$ całej analizowanej populacji, a więc zdecydowaną jej większość, a zatem skoncentrujemy się na analizie zachowań tejże grupy. 


\section{Kontynuacja studiów - analiza zachowań absolwentów}

Analizę rozpoczynamy od opisu sytuacji wyboru, przed którym stoi absolwent studiów licencjackich (ryc. 1). Główne opcje, na jakie może się zdecydować, to kontynuacja nauki na studiach drugiego stopnia lub zakończenie edukacji na tym etapie, być może $\mathrm{z}$ zamiarem powrotu na studia w przyszłości. Jeśli absolwent decyduje się na kontynuację nauki, może zmienić uczelnię, kierunek studiów bądź tryb studiowania, lub dokonać kilku zmian jednocześnie. Świeżo upieczony absolwent studiów pierwszego stopnia ma więc przed sobą niemal nieograniczoną liczbę dostępnych opcji, wynikającą z kombinacji uczelni, kierunków i trybów studiowania. Należy jednak pamiętać, że ma on za sobą co najmniej trzy lata studiów na konkretnym kierunku, konkretnej uczelni i danym trybie studiowania, co stanowi bardzo istotne doświadczenie z punktu widzenia dalszej edukacji. Dlatego, sytuację wyboru absolwenta opiszemy syntetycznie jako ograniczoną do trzech opcji: kontynuacji nauki na tej samej uczelni, na tym samym kierunku oraz $\mathrm{w}$ tym samym trybie; kontynuacji nauki ze zmianą uczelni, kierunku lub trybu studiów; przerwania edukacji.

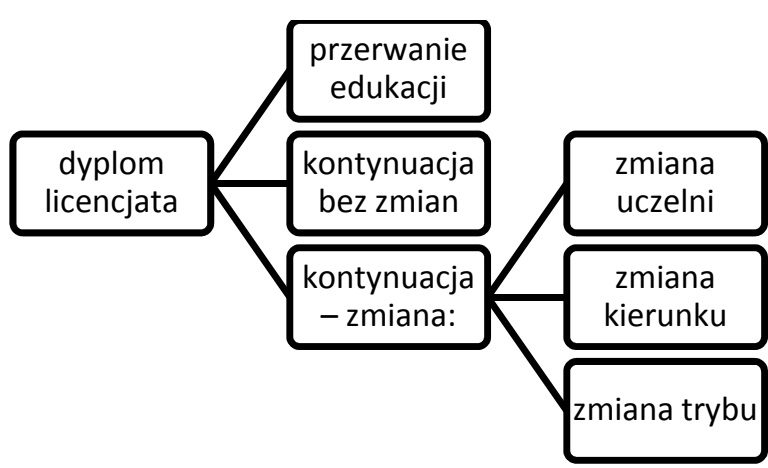

Ryc. 1. Schemat decyzyjny

$\mathrm{Na}$ podstawie danych rejestrowych Uniwersytetu Warszawskiego niemożliwe jest rozróżnienie zmiany uczelni i zakończenia edukacji. Z punktu widzenia dostępnych rejestrów obydwa przypadki są wyjściem z UW. Schemat decyzyjny oparty na danych przedstawiony jest na rycinie 2 . 


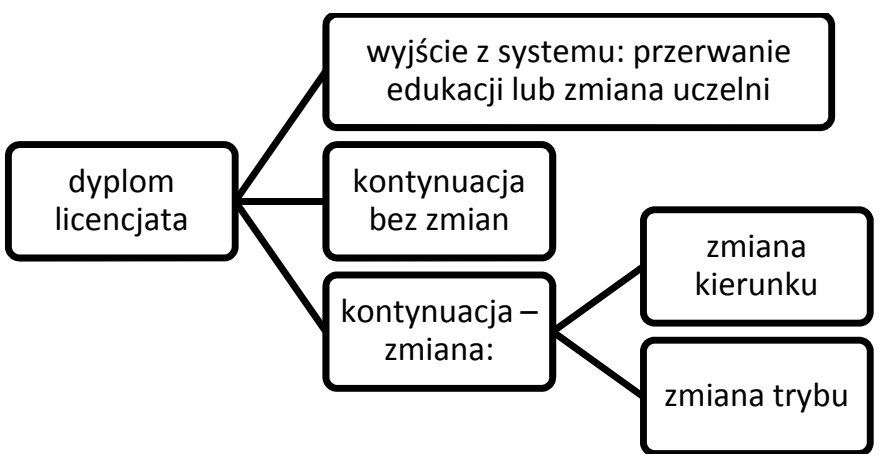

Ryc. 2. Schemat decyzyjny oparty na danych rejestrowych ${ }^{12}$

W tym miejscu przyjrzymy się dwóm opcjom obecnym na rycinie 1 , których z punktu widzenia rejestrów UW nie możemy rozróżnić, a więc przerwaniu edukacji oraz zmianie uczelni. Zasygnalizujemy tu jedynie pewne kwestie, które warto byłoby zbadać w przyszłości. Podobnie jak w przypad$\mathrm{ku}$ dalszych analiz, postaramy się wskazać koszty i korzyści powiązane z opcjami, na które może zdecydować się absolwent studiów pierwszego stopnia.

Korzyści płynące z kontynuacji nauki to nabywanie kompetencji, a jeśli studia zakończone są obroną dyplomu - również certyfikatu, który może być w przyszłości doceniony na rynku pracy. Pracodawcy mogą przy tym mniej lub bardziej zwracać uwagę na te dwa typy efektów, do jakich prowadzi ukończenie studiów. Obecnie w analizach decyzji edukacyjnych zwraca się na ogół uwagę na oba te aspekty, tj. opiera się je nie tylko na teoriach dotyczących kapitału ludzkiego, ale też wzbogaca o koncepcje związane z teorią sygnalizacji, według której dyplom uczelni jest istotny nie tylko jako informacja o wiedzy czy umiejętnościach, ale także o innych cechach, które mogą wyróżniać absolwenta na rynku pracy ${ }^{13}$. Jest to zgodne z postrzeganiem decyzji edukacyjnych jako inwestycji, która może się w przyszłości zwrócić, ale wiąże się jednak z pewnymi kosztami ${ }^{14}$. Kontynuacja nauki, szczególnie na studiach stacjonarnych, oznacza zazwyczaj opóźnienie wej-

12 Ze względów technicznych (m.in. w niektórych przypadkach nie jest możliwe dokładne dopasowanie programów studiów I i II stopnia) zamiast samego kierunku studiów wykorzystano dane o pozostaniu w tej samej jednostce dydaktycznej. Rozpoczęcie studiów w tej samej jednostce dydaktycznej będziemy zatem traktować jako kontynuację studiów na tym samym kierunku.

$13 \mathrm{O}$ różnicach między teoriami np. A. Weiss, Human capital vs. signalling explanations of wages, The Journal of Economic Perspectives, 1995, 9, 4, s. 133-154.

${ }^{14}$ M.in. R. Breen, J.H. Goldthorpe, Wyjaśnianie zróżnicowań edukacyjnych. 
ścia na rynek pracy. Biorąc pod uwagę jedynie te dwa czynniki, absolwent studiów pierwszego stopnia musi rozważyć, czy przyszłe korzyści płynące ze studiowania zrekompensują utracone korzyści płynące z wcześniejszego podjęcia pracy $\mathrm{w}$ pełnym wymiarze godzin. W skali makro wyniki takich porównań obrazują współczynniki zwrotu z edukacji, których wartość bardzo silnie zależy od kontekstu społeczno-ekonomicznego ${ }^{15}$.

Przy okazji warto zwrócić uwagę również na czynniki kulturowe. Dla absolwenta studiów licencjackich mogą liczyć się przecież opinie rodziny, przyjaciół oraz innych grup odniesienia. Należy tu pamiętać, że studia licencjackie to w Polsce zjawisko nadal dość nowe i spora część przedstawicieli starszych pokoleń może traktować dyplom licencjata jako stopień przejściowy, a nie docelowy w drodze do uzyskania wykształcenia wyższego. $\mathrm{Na}$ relację preferencji między kontynuacją a wyjściem z systemu edukacji mają zatem wpływ: nie tylko sytuacja na rynku pracy, postawy pracodawców wobec absolwentów studiów pierwszego i drugiego stopnia, kulturowa akceptacja studiów pierwszego stopnia, ale także rozmaite cechy indywidualne absolwenta. Na przykład, większe zasoby ekonomiczne rodziny absolwenta mogą pozwolić mu na poniesienie kosztów opóźnienia wejścia na rynek pracy, podczas gdy w przypadku absolwentów z uboższych środowisk, koszty te musiałby ponieść samodzielnie.

Odnośnie zmiany uczelni, może ona wiązać się z rozmaitymi kosztami, jak na przykład konieczność aklimatyzacji w nowym środowisku, a jeśli nowa uczelnia znajduje się $\mathrm{w}$ innym mieście - również zmianą miejsca zamieszkania. Tymczasem, młodzi ludzie w Polsce są mało mobilni i na przykład na etapie rekrutacji na studia pierwszego stopnia rozważają raczej więcej różnych kierunków studiów niż miast, w których mogliby studiować16. Zmiana taka może też wiązać się z korzyściami. Na przykład, jeśli absolwent studiów pierwszego stopnia uzyskał dyplom na mniej preferowanej przez siebie uczelni, ponieważ na tę bardziej preferowaną się nie dostał, rekrutacja na studia drugiego stopnia może stanowić okazję do zmiany uczelni właśnie na tę bardziej preferowaną już na etapie wyboru studiów pierwszego stopnia. Warto pamiętać, że pewne kierunki studiów oferowane są tylko na niektórych uczelniach. Zmiana uczelni nie musi być wyrazem preferowania jej nad inne, ale koniecznością wynikającą z wyboru przez daną osobę konkretnego kierunku studiów.

15 M.in. OECD, Education at a Glance: OECD Indicators, 2014.

${ }^{16}$ M. Herbst, A. Sobotka, Mobilność społeczna i przestrzenna w kontekście wyborów edukacyjnych. Raport z badania, Warszawa 2014. 


\section{Kontynuacja nauki na UW}

Na początku postaramy się odpowiedzieć na pytanie, czy absolwenci są w ogóle zainteresowani studiami drugiego stopnia na UW, tj. czy biorą udział w rekrutacji. W kolejnych latach można zauważyć podobną zależność odsetka absolwentów biorących udział w rekrutacji na studia drugiego stopnia od okresu, w którym dyplom uzyskano. Osoby, które otrzymały dyplom w pierwszym i ostatnim kwartale znacznie rzadziej niż pozostali absolwenci ubiegały się o przyjęcie na studia drugiego stopnia. Z punktu widzenia uczelni zdecydowanie bardziej interesujące są decyzje osób, które ukończyły studia w drugim i trzecim kwartale. Stanowią one bowiem zdecydowaną większość absolwentów studiów pierwszego stopnia. Wśród otrzymujących dyplom w okresie od kwietnia do września zdecydowanie dominują osoby zainteresowane kontynuacją nauki na Uniwersytecie Warszawskim. W kolejnych latach widoczny jest jednak systematyczny spadek zainteresowania podjęciem studiów drugiego stopnia, choć nadal utrzymuje się ono na wysokim poziomie. Wśród osób broniących się w drugim kwartale 2010 roku 86\% wzięło udział w rekrutacji na studia drugiego stopnia. Wśród broniących się w tym samym okresie w roku 2014 analogiczny odsetek wynosił 71\%. Wśród osób broniących się w trzecim kwartale, procent absolwentów pragnących kontynuować naukę na UW spadł z 83\% w 2010 roku do $73 \%$ w roku 2014.

Tabela 4

Procent absolwentów ubiegających się o przyjęcie na studia w roku uzyskania dyplomu oraz liczba absolwentów według roku i kwartału uzyskania dyplomu $(n=23884)$

\begin{tabular}{|c|c|c|c|c|c|c|c|c|c|c|}
\hline \multirow{3}{*}{$\begin{array}{l}\text { Kwartał } \\
\text { uzyskania } \\
\text { dyplomu }\end{array}$} & \multicolumn{10}{|c|}{ Rok uzyskania dyplomu } \\
\hline & \multicolumn{2}{|c|}{2010} & \multicolumn{2}{|c|}{2011} & \multicolumn{2}{|c|}{2012} & \multicolumn{2}{|c|}{2013} & \multicolumn{2}{|c|}{2014} \\
\hline & $\begin{array}{c}\text { odse- } \\
\text { tek }\end{array}$ & $\begin{array}{c}\text { liczba } \\
\text { absol- } \\
\text { wen- } \\
\text { tów } \\
\end{array}$ & $\begin{array}{c}\text { odse- } \\
\text { tek }\end{array}$ & $\begin{array}{c}\text { liczba } \\
\text { absol- } \\
\text { wen- } \\
\text { tów } \\
\end{array}$ & $\begin{array}{c}\text { odse- } \\
\text { tek }\end{array}$ & $\begin{array}{c}\text { liczba } \\
\text { absol- } \\
\text { wen- } \\
\text { tów } \\
\end{array}$ & $\begin{array}{c}\text { odse- } \\
\text { tek }\end{array}$ & $\begin{array}{c}\text { liczba } \\
\text { absol- } \\
\text { wen- } \\
\text { tów } \\
\end{array}$ & $\begin{array}{c}\text { odse- } \\
\text { tek }\end{array}$ & $\begin{array}{c}\text { liczba } \\
\text { absol- } \\
\text { wen- } \\
\text { tów } \\
\end{array}$ \\
\hline I kwartał & $34 \%$ & 96 & $35 \%$ & 144 & $40 \%$ & 152 & $37 \%$ & 185 & $34 \%$ & 203 \\
\hline II kwartał & $86 \%$ & 1477 & $82 \%$ & 1507 & $80 \%$ & 1186 & $75 \%$ & 987 & $71 \%$ & 767 \\
\hline III kwartał & $83 \%$ & 2605 & $80 \%$ & 2739 & $78 \%$ & 3159 & $74 \%$ & 3353 & $73 \%$ & 3391 \\
\hline IV kwartał & $33 \%$ & 400 & $33 \%$ & 410 & $36 \%$ & 530 & $33 \%$ & 502 & $41 \%$ & 91 \\
\hline
\end{tabular}


Niepodjęcie studiów drugiego stopnia bezpośrednio po ukończeniu studiów pierwszego stopnia może być celową strategią. Część absolwentów stara się podjąć studia $\mathrm{w}$ roku innym niż rok ukończenia studiów. Zjawisko to dotyczy przede wszystkim osób, które uzyskały dyplom w pierwszym lub ostatnim kwartale. $W$ grupach tych odsetek ubiegających się o przyjęcie na studia drugiego stopnia wzrastał nawet o 25 punktów procentowych, jeśli były uwzględnione także rejestracje $\mathrm{z}$ lat późniejszych. Nadal były to jednak odsetki znacznie niższe aniżeli wśród osób, które kończyły studia w drugim i trzecim kwartale. Natomiast, wśród osób kończących studia w drugim i trzecim kwartale zaledwie kilka procent brało udział w rekrutacji na studia drugiego stopnia w roku innym niż rok ukończenia studiów.

Tabela 5

Procent absolwentów ubiegających się o przyjęcie na studia $\mathrm{w}$ dowolnym momencie po uzyskaniu dyplomu oraz liczba absolwentów według roku i kwartału uzyskania dyplomu (n = 23 884)

\begin{tabular}{|c|c|c|r|r|r|r|r|r|r|r|}
\hline \multirow{2}{*}{$\begin{array}{c}\text { Kwartał } \\
\text { uzyskania } \\
\text { dyplomu }\end{array}$} & \multicolumn{2}{|c|}{2010} & \multicolumn{2}{|c|}{2011} & \multicolumn{2}{|c|}{2012} & \multicolumn{2}{|c|}{2013} & \multicolumn{2}{|c|}{2014} \\
\cline { 2 - 12 } & $\begin{array}{c}\text { odse- } \\
\text { tek }\end{array}$ & $\begin{array}{c}\text { liczba } \\
\text { absol- } \\
\text { wen- } \\
\text { tów }\end{array}$ & $\begin{array}{c}\text { odse- } \\
\text { tek }\end{array}$ & $\begin{array}{c}\text { liczba } \\
\text { absol- } \\
\text { wen- } \\
\text { tów }\end{array}$ & $\begin{array}{c}\text { Roke- } \\
\text { odse- } \\
\text { tek }\end{array}$ & $\begin{array}{c}\text { liczba } \\
\text { absol- } \\
\text { wen- } \\
\text { tów }\end{array}$ & $\begin{array}{c}\text { odse- } \\
\text { tek }\end{array}$ & $\begin{array}{c}\text { liczba } \\
\text { absol- } \\
\text { wen- } \\
\text { tów }\end{array}$ & $\begin{array}{c}\text { odse- } \\
\text { tek }\end{array}$ & $\begin{array}{c}\text { liczba } \\
\text { absol- } \\
\text { wen- } \\
\text { tów }\end{array}$ \\
\hline I kwartał & $43 \%$ & 96 & $57 \%$ & 144 & $60 \%$ & 152 & $57 \%$ & 185 & $50 \%$ & 203 \\
\hline II kwartał & $88 \%$ & 1477 & $86 \%$ & 1507 & $84 \%$ & 1186 & $80 \%$ & 987 & $75 \%$ & 767 \\
\hline III kwartał & $88 \%$ & 2605 & $85 \%$ & 2739 & $84 \%$ & 3159 & $81 \%$ & 3353 & $75 \%$ & 3391 \\
\hline IV kwartał & $56 \%$ & 400 & $58 \%$ & 410 & $57 \%$ & 530 & $55 \%$ & 502 & $45 \%$ & 91 \\
\hline
\end{tabular}

Jak już wspomniano, na UW liczba kandydatów na studia drugiego stopnia rzadko przewyższa znacznie liczbę oferowanych miejsc. $Z$ reguły większość kandydatów zostaje zakwalifikowanych, czyli uzyskuje możliwość podjęcia studiów. Wśród absolwentów studiów pierwszego stopnia, którzy zdecydowali się ubiegać o przyjęcie na studia drugiego stopnia na UW niemal wszyscy zostali zakwalifikowani.

Nie wszyscy zakwalifikowani decydują się jednak na podjęcie studiów. Mimo zakwalifikowania na UW mogą na przykład podjąć studia na innej uczelni. Odsetek rezygnacji jest jednak niewielki. W efekcie, przyjętych na studia zostało w zależności od roku od $87 \%$ do $93 \%$ absolwentów, którzy wzięli udział w rekrutacji. Oznacza to, że wśród wszystkich absolwentów z lat 2010-2014 studia drugiego stopnia na UW bezpośrednio po uzyskaniu 
dyplomu licencjata podjęło $65 \%$. Udział osób przyjętych na studia wśród absolwentów był zróżnicowany w zależności od momentu ukończenia studiów. W kolejnych latach największy był wśród absolwentów, którzy dyplom uzyskali w II i III kwartale.

Tabela 6

Procent absolwentów przyjętych na studia II stopnia oraz liczba absolwentów według roku i kwartału uzyskania dyplomu $(n=23884)$

\begin{tabular}{|c|c|c|c|c|c|c|c|c|c|c|}
\hline \multirow{3}{*}{$\begin{array}{l}\text { Kwartał } \\
\text { uzyskania } \\
\text { dyplomu }\end{array}$} & \multicolumn{10}{|c|}{ Rok uzyskania dyplomu } \\
\hline & \multicolumn{2}{|c|}{2010} & \multicolumn{2}{|c|}{2011} & \multicolumn{2}{|c|}{2012} & \multicolumn{2}{|c|}{2013} & \multicolumn{2}{|c|}{2014} \\
\hline & $\begin{array}{c}\text { odse- } \\
\text { tek }\end{array}$ & $\begin{array}{c}\text { liczba } \\
\text { absol- } \\
\text { wen- } \\
\text { tów } \\
\end{array}$ & $\begin{array}{c}\text { odse- } \\
\text { tek }\end{array}$ & $\begin{array}{l}\text { liczba } \\
\text { absol- } \\
\text { wen- } \\
\text { tów } \\
\end{array}$ & $\begin{array}{l}\text { odse- } \\
\text { tek }\end{array}$ & $\begin{array}{c}\text { liczba } \\
\text { absol- } \\
\text { wen- } \\
\text { tów }\end{array}$ & $\begin{array}{c}\text { odse- } \\
\text { tek }\end{array}$ & $\begin{array}{c}\text { liczba } \\
\text { absol- } \\
\text { wen- } \\
\text { tów }\end{array}$ & $\begin{array}{c}\text { odse- } \\
\text { tek }\end{array}$ & $\begin{array}{c}\text { liczba } \\
\text { absol- } \\
\text { wen- } \\
\text { tów }\end{array}$ \\
\hline I kwartał & $30 \%$ & 96 & $29 \%$ & 144 & $36 \%$ & 152 & $32 \%$ & 185 & $31 \%$ & 203 \\
\hline II kwartał & $80 \%$ & 1477 & $77 \%$ & 1507 & $75 \%$ & 1186 & $70 \%$ & 987 & $67 \%$ & 767 \\
\hline III kwartał & $75 \%$ & 2605 & $69 \%$ & 2739 & $69 \%$ & 3159 & $67 \%$ & 3353 & $68 \%$ & 3391 \\
\hline IV kwartał & $6 \%$ & 400 & $15 \%$ & 410 & $11 \%$ & 530 & $15 \%$ & 502 & $30 \%$ & 91 \\
\hline
\end{tabular}

Wśród absolwentów studiów licencjackich na UW dominuje kontynuacja nauki na tej samej uczelni - niemal dwie trzecie absolwentów bezpośrednio po studiach pierwszego stopnia kontynuuje naukę na tej samej uczelni na studiach magisterskich (w najliczniejszej grupie absolwentów uzyskujących dyplom w typowych terminach, czyli w II i III kwartale odsetek kontynuujących przekracza dla każdego analizowanego rocznika 70\%). Jak już wspomniano, decyzja o niekontynuowaniu nauki na UW może oznaczać zarówno zakończenie edukacji na tym etapie, jak też zmianę uczelni. Prezentowane dane wskazują, że zdecydowana większość absolwentów UW preferuje jednak studia na tej uczelni nad inne opcje. Może to oznaczać z jednej strony preferowanie UW nad inne uczelnie, ale także wynikać z faktu, że część kierunków jest oferowana jedynie na tej uczelni. Wybór uczelni byłby w takim układzie sprawą niejako drugorzędną wobec wyboru kierunku studiów.

Rosnący odsetek osób nie decydujących się na kontynuację nauki na UW może świadczyć o zmianach dotyczących dwóch wymiarów decyzji podejmowanych przez absolwentów: kwestii kontynuacji nauki w ogóle oraz kwestii wyboru uczelni. Jako że dostępne dane rejestrowe dają nam możliwość określenia jedynie tego, czy absolwent wyszedł z systemu UW, tutaj jedynie sygnalizujemy to zjawisko. Zestawiając wyniki z założeniami teore- 
tycznymi przedstawionymi wcześniej, można wysunąć kilka hipotez na temat czynników, które mogły przyczynić się do pojawienia się obserwowanego trendu. Być może zmienia się postrzeganie dyplomu licencjata przez pracodawców, co daje szansę na znalezienie pełnowartościowego zatrudnienia bez konieczności kończenia studiów II stopnia. Być może spada atrakcyjność studiów na UW w porównaniu z pozostałymi uczelniami, przy jednoczesnym zmniejszeniu w oczach absolwentów kosztów zmiany uczelni. Być może także zwiększający się odsetek osób przerywających naukę wynika z rosnących kosztów związanych ze studiami (w tym utrzymania). $\mathrm{Na}$ tym etapie są to jednak tylko przypuszczenia, do weryfikacji których konieczne jest przeprowadzenie badań dodatkowych. $Z$ pewnością, warto byłoby przeanalizować skalę i trendy dotyczące wyjść z systemu oraz zmian uczelni, a także kierunki przepływów między uczelniami, dysponując szerszymi danymi umożliwiającymi rozróżnienie dwóch omawianych wyżej, a jakościowo różnych sytuacji.

Widoczna jest też ogromna różnica między wyborami dokonywanymi przez absolwentów, którzy uzyskali dyplom w terminie (w zależności od rocznika grupa ta, jak już wspomniano, stanowi 86-93\% badanej populacji) a tymi, którzy uzyskali dyplom w pierwszym lub ostatnim kwartale. Porównanie średnich ocen tych dwóch grup prowadziło do wniosku, że występują albo różnice $\mathrm{w}$ kompetencjach, albo w zaangażowaniu w studiowanie między tymi dwoma grupami absolwentów, albo też mamy do czynienia z kombinacją różnic dotyczących obu cech. Jeśli osoby broniące się z opóźnieniem są mniej zmotywowane do nauki, to $\mathrm{w}$ ich przypadku opóźnienie mogło być nie tyle przyczyną, co skutkiem decyzji o niekontynuowaniu nauki. Innymi słowy, osoby takie mogły już wcześniej podjąć decyzję, że nie będą kontynuowały nauki i nie podjęły w związku z tym wysiłku w celu zdobycia dyplomu $\mathrm{w}$ terminie.

\section{Kontynuacja studiów w tej samej jednostce}

Przyjrzyjmy się teraz decyzji o wyborze kierunku oraz trybu studiów. W obydwu przypadkach, żeby absolwent zdecydował się na zmianę, korzyści z niej płynące powinny przewyższać koszty. W pierwszej kolejności przeanalizujemy, jak często absolwenci studiów pierwszego stopnia korzystają z danej im przez proces boloński możliwości zmiany kierunku studiów po uzyskaniu dyplomu licencjata. $Z$ tej części analizy zostali wyłączeni absolwenci jednostek, które nie oferują studiów drugiego stopnia, takich jak 
Uniwersyteckie Kolegium Kształcenia Nauczycieli Języka Niemieckiego. Oznacza to wykluczenie 1212 obserwacji.

W zdecydowanej większości przypadków objęci analizą absolwenci rejestrując się na studia drugiego stopnia, wybierali studia w tej samej jednostce dydaktycznej. Spośród absolwentów kończących studia w drugim oraz trzecim kwartale i planujących kontynuację nauki na UW, 90\% wybiera studia oferowane przez jednostkę dydaktyczną, w której wcześniej studiowali. W obserwowanym okresie widać jednak powolny spadek odsetka osób zainteresowanych kontynuacją studiów $\mathrm{w}$ tej samej jednostce (niezależny od spadku zainteresowania kontynuacją studiów na UW). Osoby, które kończyły studia $\mathrm{w}$ nietypowych terminach (pierwszym i ostatnim kwartale), w mniejszym stopniu niż pozostali absolwenci są zainteresowane studiami w tej samej jednostce.

Tabela 7

Procent absolwentów ubiegających się o przyjęcie na studia w tej samej jednostce dydaktycznej w roku uzyskania dyplomu wśród osób, które ubiegały się o przyjęcie na studia II stopnia na UW oraz liczba osób ubiegających się o przyjęcie na studia II stopnia na UW według roku i kwartału uzyskania dyplomu $(n=18$ 103)

\begin{tabular}{|c|c|c|c|c|c|c|c|c|c|c|}
\hline \multirow[b]{3}{*}{$\begin{array}{c}\text { Kwartał } \\
\text { uzyskania } \\
\text { dyplomu }\end{array}$} & \multicolumn{10}{|c|}{ Rok uzyskania dyplomu } \\
\hline & \multicolumn{2}{|c|}{2010} & \multicolumn{2}{|c|}{2011} & \multicolumn{2}{|c|}{2012} & \multicolumn{2}{|c|}{2013} & \multicolumn{2}{|c|}{2014} \\
\hline & $\begin{array}{c}\text { odse- } \\
\text { tek }\end{array}$ & $\begin{array}{l}\text { liczba } \\
\text { ubie- } \\
\text { gają- } \\
\text { cych } \\
\text { się o } \\
\text { przy- } \\
\text { jęcia } \\
\text { na } \\
\text { studia } \\
\text { II s. } \\
\end{array}$ & $\begin{array}{c}\text { od- } \\
\text { setek }\end{array}$ & $\begin{array}{c}\text { liczba } \\
\text { ubiega- } \\
\text { jących } \\
\text { się o } \\
\text { przyję- } \\
\text { cia na } \\
\text { studia } \\
\text { II s. }\end{array}$ & $\begin{array}{l}\text { od- } \\
\text { se- } \\
\text { tek }\end{array}$ & $\begin{array}{c}\text { liczba } \\
\text { ubiega- } \\
\text { jących } \\
\text { się } \\
\text { o przy- } \\
\text { jęcia na } \\
\text { studia } \\
\text { II s. }\end{array}$ & $\begin{array}{c}\text { odse- } \\
\text { tek }\end{array}$ & $\begin{array}{c}\text { liczba } \\
\text { ubie- } \\
\text { gają- } \\
\text { cych } \\
\text { się o } \\
\text { przyję- } \\
\text { cia na } \\
\text { studia } \\
\text { II s. }\end{array}$ & $\begin{array}{l}\text { od- } \\
\text { se- } \\
\text { tek }\end{array}$ & $\begin{array}{c}\text { liczba } \\
\text { ubiega- } \\
\text { jących } \\
\text { się o } \\
\text { przyję- } \\
\text { cia na } \\
\text { studia } \\
\text { II s. }\end{array}$ \\
\hline I kwartał & $67 \%$ & 33 & $70 \%$ & 73 & $76 \%$ & 86 & $71 \%$ & 91 & $67 \%$ & 96 \\
\hline II kwartał & $93 \%$ & 1249 & $93 \%$ & 1206 & $91 \%$ & 923 & $88 \%$ & 790 & $86 \%$ & 492 \\
\hline III kwartał & $93 \%$ & 2225 & $92 \%$ & 2268 & $90 \%$ & 2538 & $88 \%$ & 2586 & $88 \%$ & 2418 \\
\hline IV kwartał & $76 \%$ & 196 & $75 \%$ & 225 & $76 \%$ & 295 & $81 \%$ & 272 & $93 \%$ & 41 \\
\hline
\end{tabular}

Na początku zastanówmy się, co może sprawiać, że zdecydowana większość osób planujących kontynuację nauki na UW nie chce zmieniać kierunku studiów. Wydaje się, że decydujące mogą być dwa czynniki: szeroko 
rozumiana atrakcyjność dotychczasowego kierunku studiów oraz wysokie koszty zmiany kierunku.

Na atrakcyjność kierunku mogą się składać zgodność przedmiotów z zainteresowaniami, przekonanie, że po takim kierunku łatwo znaleźć pracę, a nawet tak z pozoru błahe kwestie jak dogodny plan zajęć, przyzwyczajenia, czy położenie jednostki dydaktycznej. Należy w tym miejscu podkreślić, że mamy do czynienia z absolwentami, a nie kimś, kto wybiera swój pierwszy kierunek studiów. Dyplom licencjata oznacza, że dana osoba nie tylko wybrała dany kierunek ze względu na jego atrakcyjność, ale też przeszła przez wszystkie etapy selekcji na studiach. Ponadto, absolwent miał już wiele okazji, żeby kierunek zmienić lub porzucić, a tego nie zrobił. Wyniki ankiet prowadzonych regularnie wśród studentów UW wskazują natomiast na wysoki poziom zadowolenia ze studiów ${ }^{17}$.

Drugim czynnikiem zniechęcającym do zmiany kierunku może być bariera w postaci wysokich kosztów zmiany kierunku. Wynika ona ze struktury programów studiów obowiązującej w polskim systemie edukacji na poziomie wyższym. Na pierwszym stopniu studiów nie ma programów o charakterze ogólnym. Już od samego początku studia są bardzo wyspecjalizowane i występują bardzo duże różnice pomiędzy pokrewnymi kierunkami studiów. Koszt zmiany kierunku wynika w efekcie przede wszystkim z konieczności zmierzenia się z nowymi przedmiotami bez posiadania bazy wiedzy i umiejętności, jaką dysponują studenci kontynuujący naukę na swoim kierunku studiów. Nawet jeśli formalnie nie jest konieczne uzupełnianie wiedzy bazowej, to jednak np. przedmiot „Programowanie współbieżne i rozproszone" - obowiązkowy na pierwszym roku informatyki na studiach drugiego stopnia - może być znacznie trudniejszy dla kogoś, kto na studiach pierwszego stopnia nie miał zbyt wiele do czynienia z programowaniem, niż dla kogoś kto uzyskał licencjat $\mathrm{z}$ informatyki. Z jednej strony, koszty związane z koniecznością nadrabiania pewnych zaległości czy uzupełniania braków w wiedzy są tym większe, im bardziej różnią się kierunek ukończony i docelowy, a więc im mniejszy jest ich wspólny „rdzeń". Z drugiej strony, minimalizacja kosztu zmiany kierunku prowadzi do wyboru kierunku pokrewnego. W takim wypadku trudno spodziewać się, że będzie on znacząco bardziej dopasowany do zainteresowań absolwenta lub będzie dawać dużo lepszą pozycję na rynku pracy, co istotnie zmniejsza korzyści ze zmiany kierunku.

17 A. Izdebski i in., Ogólnouniwersytecka Ankieta Oceniająca Jakość Kształcenia. IV edycja. Raport z badania, Warszawa 2012. 
Rosnący odsetek osób zmieniających kierunek można interpretować jako wynik zmian w postrzeganiu kosztów i korzyści. Z jednej strony, w ostatnich latach faktycznie mogły zmniejszyć się bariery, np. zmieniło się podejście jednostek dydaktycznych do osób niebędących ich absolwentami. $\mathrm{Z}$ drugiej strony, mogła zmienić się percepcja barier. Na przykład, zachęceni doświadczeniami osób, które zmieniły kierunek studiów, absolwenci mogą obecnie postrzegać koszty zmiany kierunku jako niższe aniżeli jeszcze kilka lat temu.

\section{Kontynuacja nauki a tryb studiów}

Tryb studiów stanowi istotny czynnik różnicujący przebieg ścieżek edukacyjnych. Jak już pisaliśmy, w kolejnych latach zmniejsza się udział absolwentów studiów niestacjonarnych, co po części wynika z większego odpadu (ang. dropout) w trakcie studiów. Ponadto, absolwenci studiów niestacjonarnych wyraźnie częściej występują wśród osób kończących studia w nietypowych terminach, czyli w pierwszym i ostatnim kwartale roku. Z trybem studiów powiązane są także decyzje dotyczące kontynuacji studiów. W kolejnych latach najwyższy odsetek osób ubiegających się o przyjęcie na studia widać wśród osób, które ukończyły studia stacjonarne, a najniższy - wśród absolwentów studiów niestacjonarnych zaocznych.

Tabela 8

Procent absolwentów, którzy ubiegali się o przyjęcie na studia w roku uzyskania dyplomu oraz liczba absolwentów według roku uzyskania dyplomu i trybu studiów pierwszego stopnia $(n=22527)$

\begin{tabular}{|c|c|c|c|c|c|c|c|c|c|c|}
\hline \multirow{3}{*}{$\begin{array}{c}\text { Tryb stu- } \\
\text { diów pierw- } \\
\text { szego stop- } \\
\text { nia }\end{array}$} & \multicolumn{10}{|c|}{ Rok uzyskania dyplomu } \\
\hline & \multicolumn{2}{|c|}{2010} & \multicolumn{2}{|c|}{2011} & \multicolumn{2}{|c|}{2012} & \multicolumn{2}{|c|}{2013} & \multicolumn{2}{|c|}{2014} \\
\hline & $\begin{array}{c}\text { odse- } \\
\text { tek }\end{array}$ & $\begin{array}{c}\text { liczba } \\
\text { absol- } \\
\text { sol- } \\
\text { wen- } \\
\text { tów }\end{array}$ & $\begin{array}{c}\text { odse- } \\
\text { tek }\end{array}$ & $\begin{array}{c}\text { liczba } \\
\text { absol- } \\
\text { sol- } \\
\text { wen- } \\
\text { tów }\end{array}$ & $\begin{array}{c}\text { odse- } \\
\text { tek }\end{array}$ & $\begin{array}{c}\text { liczba } \\
\text { absol- } \\
\text { sol- } \\
\text { wen- } \\
\text { tów } \\
\end{array}$ & $\begin{array}{c}\text { odse- } \\
\text { tek }\end{array}$ & $\begin{array}{c}\text { liczba } \\
\text { absol- } \\
\text { sol- } \\
\text { wen- } \\
\text { tów }\end{array}$ & $\begin{array}{c}\text { odse } \\
\text { se- } \\
\text { tek }\end{array}$ & $\begin{array}{c}\text { liczba } \\
\text { absol- } \\
\text { sol- } \\
\text { wen- } \\
\text { tów } \\
\end{array}$ \\
\hline Stacjonarne & $85 \%$ & 3107 & $80 \%$ & 3323 & $76 \%$ & 3489 & $72 \%$ & 3726 & $73 \%$ & 3261 \\
\hline $\begin{array}{l}\text { Niestacjo- } \\
\text { narne wie- } \\
\text { czorowe }\end{array}$ & $78 \%$ & 633 & $75 \%$ & 697 & $70 \%$ & 743 & $65 \%$ & 562 & $63 \%$ & 429 \\
\hline $\begin{array}{l}\text { Niestacjo- } \\
\text { narne za- } \\
\text { oczne }\end{array}$ & $59 \%$ & 601 & $59 \%$ & 504 & $61 \%$ & 514 & $54 \%$ & 536 & $60 \%$ & 402 \\
\hline
\end{tabular}


Tabela 9

Procent absolwentów studiów I stopnia ubiegających się o przyjęcie na studia II stopnia, którzy dokonali rejestracji na studia w poszczególnych trybach według roku uzyskania dyplomu oraz trybu ukończonych studiów $(\mathrm{n}=22527)$

\begin{tabular}{|c|c|c|c|c|c|}
\hline \multirow[b]{2}{*}{$\begin{array}{l}\text { Rok ukoń- } \\
\text { czenia } \\
\text { studiów }\end{array}$} & \multirow[b]{2}{*}{$\begin{array}{l}\text { Tryb ukończo- } \\
\text { nych studiów }\end{array}$} & \multirow[b]{2}{*}{$\begin{array}{l}\text { Liczba } \\
\text { absolwen- } \\
\text { tów }\end{array}$} & \multicolumn{3}{|c|}{ Rejestracja - tryb studiów } \\
\hline & & & $\begin{array}{l}\text { stacjo- } \\
\text { narne }\end{array}$ & $\begin{array}{l}\text { niestacjo- } \\
\text { narne wie- } \\
\text { czorowe }\end{array}$ & $\begin{array}{c}\text { niestacjo- } \\
\text { narne } \\
\text { zaoczne }\end{array}$ \\
\hline \multirow{3}{*}{2010} & stacjonarne & 3107 & $97 \%$ & $8 \%$ & $9 \%$ \\
\hline & $\begin{array}{l}\text { niestacjonarne } \\
\text { wieczorowe }\end{array}$ & 633 & $67 \%$ & $49 \%$ & $44 \%$ \\
\hline & $\begin{array}{l}\text { niestacjonarne } \\
\text { zaoczne }\end{array}$ & 601 & $13 \%$ & $3 \%$ & $96 \%$ \\
\hline \multirow{3}{*}{2011} & stacjonarne & 3323 & $97 \%$ & $6 \%$ & $8 \%$ \\
\hline & $\begin{array}{l}\text { niestacjonarne } \\
\text { wieczorowe }\end{array}$ & 697 & $72 \%$ & $46 \%$ & $34 \%$ \\
\hline & $\begin{array}{l}\text { niestacjonarne } \\
\text { zaoczne }\end{array}$ & 504 & $14 \%$ & $3 \%$ & $91 \%$ \\
\hline \multirow{3}{*}{2012} & stacjonarne & 3489 & $96 \%$ & $4 \%$ & $8 \%$ \\
\hline & $\begin{array}{l}\text { niestacjonarne } \\
\text { wieczorowe }\end{array}$ & 743 & $66 \%$ & $32 \%$ & $44 \%$ \\
\hline & $\begin{array}{l}\text { niestacjonarne } \\
\text { zaoczne }\end{array}$ & 514 & $8 \%$ & $2 \%$ & $95 \%$ \\
\hline \multirow{3}{*}{2013} & stacjonarne & 3726 & $96 \%$ & $4 \%$ & $10 \%$ \\
\hline & $\begin{array}{l}\text { niestacjonarne } \\
\text { wieczorowe }\end{array}$ & 562 & $71 \%$ & $36 \%$ & $42 \%$ \\
\hline & $\begin{array}{l}\text { niestacjonarne } \\
\text { zaoczne }\end{array}$ & 536 & $10 \%$ & $1 \%$ & $94 \%$ \\
\hline \multirow{3}{*}{2014} & stacjonarne & 3261 & $96 \%$ & $3 \%$ & $9 \%$ \\
\hline & $\begin{array}{l}\text { niestacjonarne } \\
\text { wieczorowe }\end{array}$ & 429 & $74 \%$ & $26 \%$ & $40 \%$ \\
\hline & $\begin{array}{l}\text { niestacjonarne } \\
\text { zaoczne }\end{array}$ & 402 & $12 \%$ & $2 \%$ & $94 \%$ \\
\hline
\end{tabular}

Uwaga: absolwenci mogli ubiegać się o przyjęcie na więcej niż jeden kierunek, dlatego odsetki nie sumują się do $100 \%$.

Od trybu ukończonych studiów w dużym stopniu zależy również wybór trybu studiów drugiego stopnia. W poszczególnych latach niemal wszystkie osoby, które ukończyły studia stacjonarne lub niestacjonarne zaoczne i zdecydowały się wziąć udział $\mathrm{w}$ rekrutacji na studia drugiego stopnia na Uniwersytecie Warszawskim wybierały w czasie rejestracji studia w tym samym trybie co ukończone studia pierwszego stopnia. Studia $\mathrm{w}$ innych trybach wybierało do kilkunastu procent absolwentów z opisanej powyżej grupy. 
Dla osób, które ukończyły studia niestacjonarne wieczorowe rekrutacja na studia drugiego stopnia jest okazją do zmiany trybu studiów. We wszystkich latach objętych analizą absolwenci studiów niestacjonarnych wieczorowych zdecydowanie częściej wybierali w czasie rekrutacji studia stacjonarne niż studia wieczorowe.

Uwzględniając tryb studiów, to preferencje kandydatów na studia w dużej mierze mogą zależeć od planów dotyczących łączenia studiów z pracą zawodową, szczególnie pracą w pełnym wymiarze godzin. Odsetek osób pracujących jest znacznie wyższy wśród studentów studiów niestacjonarnych zaocznych ${ }^{18}$. Dla studentów pracujących pełnoetatowo (lub $\mathrm{w}$ formie zajmującej równie dużo czasu) najbardziej preferowanym trybem ze względu na organizację zajęć są studia zaoczne. Dla pozostałych studentów korzystniejsze są studia dzienne lub wieczorowe, przy czym - co dość oczywiste - studia dzienne mają tę przewagę nad wieczorowymi, że są bezpłatne.

Korzyść płynąca ze studiów dziennych to większy prestiż takich studiów i brak opłat. Studia wieczorowe może cechować większy prestiż niż zaoczne, ale wiążą się z nimi opłaty, a łączenie ich z pracą pełnoetatową może być równie trudne, jak w przypadku dziennych. Biorąc to pod uwagę, można analizować przepływy między trybami studiów pod względem możliwych korzyści i kosztów wynikających ze zmian trybu. Ilustruje to tabela 10. Zaprezentowane koszty i korzyści odpowiadają następującym założeniom:

- pod względem postrzegania jakości i prestiżu studiów najbardziej cenione są studia stacjonarne, następnie wieczorowe, a w dalszej kolejności zaoczne;

- główną korzyścią płynącą ze studiowania w trybie zaocznym jest możliwość łączenia studiów z pracą;

- studia stacjonarne mają tę przewagę nad niestacjonarnymi, że są bezpłatne.

Tabela 10

Korzyści i koszty związane ze zmianą trybu studiów

\begin{tabular}{|l|l|l|l|l|}
\hline \multicolumn{2}{|c|}{} & \multicolumn{3}{|c|}{ Zmiana trybu na: } \\
\cline { 3 - 5 } \multicolumn{2}{c|}{} & stacjonarne & $\begin{array}{l}\text { niestacjonarne } \\
\text { wieczorowe }\end{array}$ & $\begin{array}{c}\text { niestacjonarne } \\
\text { zaoczne }\end{array}$ \\
\hline $\begin{array}{l}\text { Tryb } \\
\text { ukończonych } \\
\text { studiów }\end{array}$ & stacjonarne & b.z. & $\begin{array}{l}\text { - niższy prestiż, } \\
\text { opłaty }\end{array}$ & $\begin{array}{l}\text { + większa } \\
\text { tatwość godze- } \\
\text { nia z pracą }\end{array}$ \\
\hline
\end{tabular}

18 M. Jasiński i in., Ogólnouniwersytecka ankieta oceniająca jakość ksztatcenia. Trzecia edycja. Raport, Warszawa 2010. 


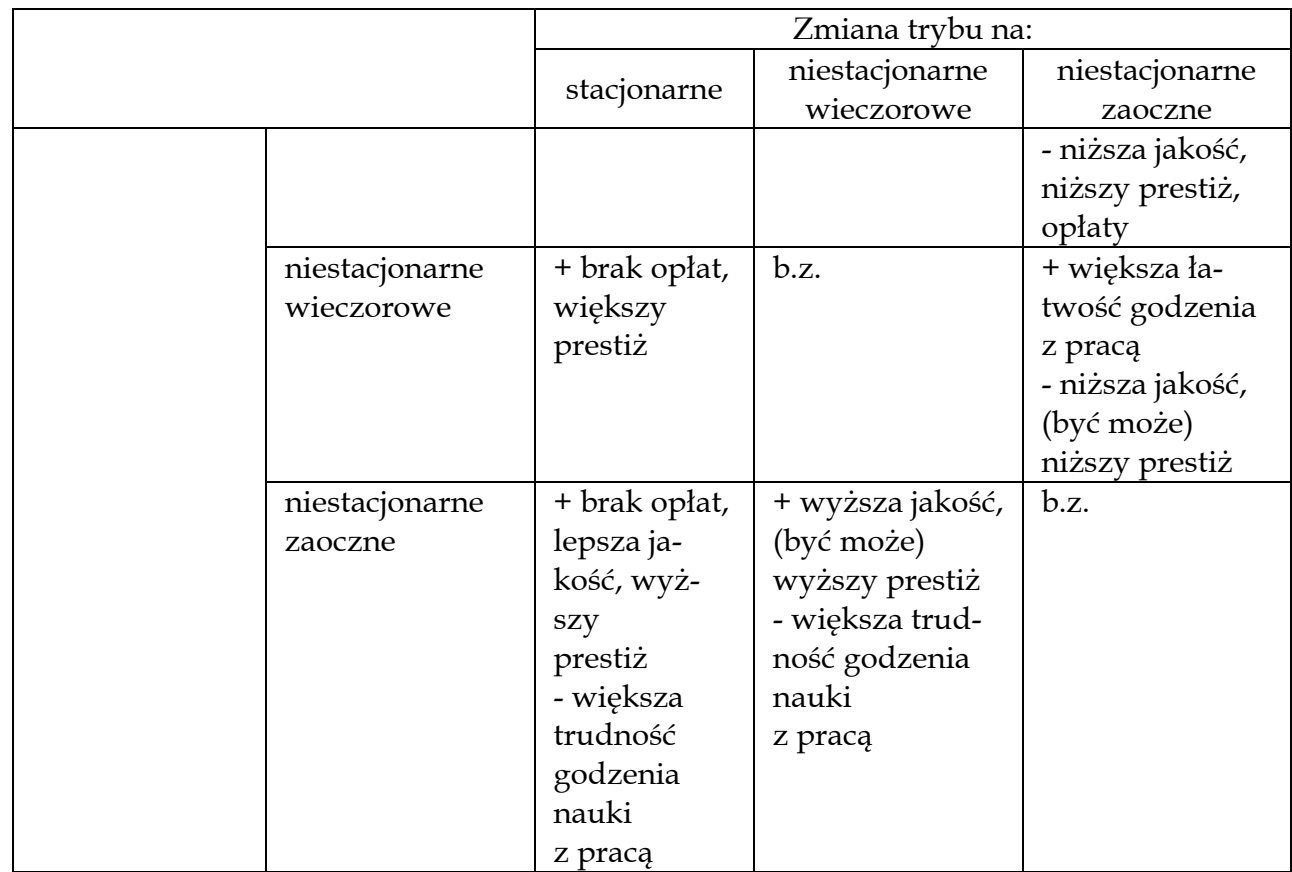

Dane na temat wyborów dokonywanych przez absolwentów wyraźnie wskazują, że najmniej preferowany jest tryb wieczorowy. Przejście na tryb wieczorowy nie wydaje się opłacalne ani dla osób, które studiowały w trybie stacjonarnym, ani dla absolwentów studiów zaocznych. Dla tych pierwszych nie wiąże się z żadnymi korzyściami, a dla drugich - i to mówią nam wybory dokonywane przez absolwentów studiów zaocznych - z mniejszymi korzyściami niż w przypadku studiów stacjonarnych. $W$ tabeli 11 zaprezentowano zbiorcze zestawienie danych z tabeli 9.

Tabela 11

Procent absolwentów studiów I stopnia ubiegających się o przyjęcie na studia II stopnia, którzy dokonali rejestracji na studia w poszczególnych trybach według trybu ukończonych studiów $(\mathrm{n}=22527)$

\begin{tabular}{|c|c|c|c|c|}
\hline & \multicolumn{3}{|c|}{ Rejestracja na: } \\
\hline & & stacjonarne & $\begin{array}{c}\text { niestacjonarne } \\
\text { wieczorowe }\end{array}$ & $\begin{array}{l}\text { niestacjonarne } \\
\text { zaoczne }\end{array}$ \\
\hline \multirow{3}{*}{$\begin{array}{l}\text { Tryb } \\
\text { ukończonych } \\
\text { studiów }\end{array}$} & stacjonarne & $96-97 \%$ & $3-8 \%$ & $8-10 \%$ \\
\hline & $\begin{array}{l}\text { niestacjonarne } \\
\text { wieczorowe }\end{array}$ & $66-74 \%$ & $26-49 \%$ & $34-44 \%$ \\
\hline & $\begin{array}{l}\text { niestacjonarne } \\
\text { zaoczne }\end{array}$ & $8-14 \%$ & $1-3 \%$ & $91-96 \%$ \\
\hline
\end{tabular}

Uwaga: w tabeli podano zakres odsetków dla wszystkich analizowanych roczników. 
W przypadku absolwentów studiów stacjonarnych i zaocznych najczęściej wybierany jest ten sam tryb studiów, podczas gdy absolwenci studiów wieczorowych wykorzystują okazję do zmiany trybu studiowania. Część $\mathrm{z}$ nich rejestruje się wprawdzie na studia prowadzone $\mathrm{w}$ trybie zaocznym, co może wynikać ze stosowania strategii asekuracyjnej, to znaczy - osoby te rejestrują się na studia wieczorowe na wypadek niedostania się na studia stacjonarne.

Analiza przyjęć na studia drugiego stopnia, a więc nie samej rejestracji na dany kierunek, ale podjęcia na nim studiów, jeszcze wyraźniej ilustruje zależność opisaną już wcześniej (tab. 12).

Tabela 12

Procent absolwentów studiów I stopnia przyjętych na studia II stopnia wśród tych, którzy dokonali rejestracji na studia w poszczególnych trybach według trybu ukończonych studiów $(\mathrm{n}=22$ 527)

\begin{tabular}{|l|l|c|c|c|}
\hline \multicolumn{2}{|c|}{} & \multicolumn{3}{|c|}{ Odsetek przyjętych na studia... } \\
\cline { 2 - 5 } \multicolumn{2}{|c|}{} & stacjonarne & $\begin{array}{c}\text { niestacjonarne } \\
\text { wieczorowe }\end{array}$ & $\begin{array}{c}\text { niestacjonarne } \\
\text { zaoczne }\end{array}$ \\
\hline \multirow{3}{*}{$\begin{array}{l}\text { Tryb } \\
\text { ukończonych } \\
\text { studiów }\end{array}$} & stacjonarne & $\mathbf{9 5 - 9 6 \%}$ & $1 \%$ & $4-6 \%$ \\
\cline { 2 - 5 } & $\begin{array}{l}\text { niestacjonarne } \\
\text { wieczorowe }\end{array}$ & $\mathbf{5 4 - 6 4 \%}$ & $10-20 \%$ & $24-29 \%$ \\
\cline { 2 - 5 } & $\begin{array}{l}\text { niestacjonarne } \\
\text { zaoczne }\end{array}$ & $5-13 \%$ & $0-1 \%$ & $\mathbf{8 7 - 9 4 \%}$ \\
\hline
\end{tabular}

Uwaga: w tabeli podano zakres odsetków dla wszystkich analizowanych roczników.

Przejście na studia drugiego stopnia jest okazją dla absolwentów studiów wieczorowych na zmianę trybu nauki. Ponad połowa (w różnych latach 54-64\%) wybiera studia stacjonarne wiążące się z większym prestiżem, a przede wszystkim pozbawione opłat, natomiast około jedna czwarta (24$29 \%$ ) wybiera studia zaoczne, które umożliwiają łatwiejsze łączenie nauki z pracą zawodową. Wśród absolwentów studiów wieczorowych na studia w tym samym trybie decydowało się w ostatnich latach $10-20 \%$ osób. Choć, jak podkreślaliśmy, tryb ten wydaje się mało korzystny, to podjęcie takich studiów może być rozwiązaniem dla osób, które spóźniły się z terminem obrony na rekrutację na studia stacjonarne. Absolwenci studiów stacjonarnych oraz zaocznych w zdecydowanej większości pozostają przy dotychczasowym trybie studiów (odpowiednio: 95-96\% i 87-94\% absolwentów). 


\section{Podsumowanie}

Celem niniejszego artykułu była analiza decyzji absolwentów studiów pierwszego stopnia dotyczących kontynuacji nauki na drugim stopniu studiów na przykładzie danych z Uniwersytetu Warszawskiego. Przeanalizowaliśmy zapisy pochodzące z systemów administracyjnych dotyczące decyzji podjętych przez populację osób kończących studia na tej uczelni w latach 2010-2014. Skorzystaliśmy przy tym z założeń teorii racjonalnego wyboru: metodologicznego indywidualizmu i racjonalności aktorów. Na podstawie wyborów dokonywanych przez osoby, które ukończyły studia pierwszego stopnia na UW staraliśmy się odtworzyć preferencje absolwentów oraz zwrócić uwagę na koszty i korzyści, które mogły w istotnym stopniu wpływać na ich decyzje.

Okazało się, że absolwenci UW najczęściej kontynuują naukę na tej samej uczelni. Niemal dwie trzecie absolwentów UW z lat 2010-2014 podjęło studia drugiego stopnia na UW bezpośrednio po uzyskaniu dyplomu licencjata. Najczęstszą decyzją absolwentów studiów pierwszego stopnia na UW jest kontynuacja nauki na tym samym kierunku i na ogół w tym samym trybie co dopiero ukończony (wyjątkiem są absolwenci studiów wieczorowych). Absolwenci kończący studia w terminie i decydujący się na kontynuację nauki na UW rejestrując się na studia drugiego stopnia, w blisko $90 \%$ wybierają studia oferowane przez jednostkę dydaktyczną, w której wcześniej studiowali. Świadczy to $\mathrm{z}$ jednej strony o atrakcyjności dotychczasowych studiów, ale też o barierach zniechęcających do zmiany kierunku. Należy pamiętać, że osoby $\mathrm{z}$ różnych względów uważające swoje studia za niewystarczająco atrakcyjne lub zbyt trudne, często nie uzyskują dyplomu, toteż zmiany kierunku dokonują nie tyle na progu edukacyjnym, jakim jest koniec studiów pierwszego stopnia, ale jeszcze przed nim. Moment ten jest natomiast wykorzystywany do zmiany trybu studiów przez osoby, które ukończyły studia wieczorowe, z różnych względów mniej korzystne niż studia stacjonarne i zaoczne.

Uwzględniając trendy obserwowane $\mathrm{w}$ ostatnich latach, zauważa się powolny, choć systematyczny spadek zainteresowania absolwentów podjęciem studiów drugiego stopnia. Nadal jednak utrzymuje się ono na wysokim poziomie. $W$ obserwowanym okresie widać również powolny spadek odsetka osób zainteresowanych kontynuacją studiów w tej samej jednostce, niezależny od spadku zainteresowania kontynuacją studiów na UW. Dane rejestrowe nie zawierają informacji odnośnie motywacji absolwentów można jednak pokusić się o pewne hipotezy. Skoro sam system rekrutacji na studia drugiego stopnia nie zmieniał się znacząco w latach objętych obser- 
wacją, zmiany w zachowaniach kandydatów wynikają zapewne ze zmian ich preferencji. Na preferencje te mogą natomiast wpływać na przykład większa akceptacja dla licencjatu jako dyplomu ukończenia studiów, a nie tylko stanu przejściowego, przyzwyczajanie pracodawców do tego rodzaju dyplomu oraz obniżanie barier dotyczących zmiany kierunku studiów.

Rozważając ograniczenia prezentowanych wyników, należy przede wszystkim podkreślić, że na podstawie dostępnych danych możliwe było przeprowadzenie analizy wyłącznie dla Uniwersytetu Warszawskiego. Nie można odpowiedzieć na pytanie, czy rezygnacja z dalszej nauki na UW jest jednoznaczna z rezygnacją ze studiów w ogóle. Odpowiedź na pytanie dotyczące przepływu studentów między uczelniami wymagałaby albo wymiany informacji między uczelniami, albo wykorzystania scentralizowanego rejestru studentów, jakim jest POL-on. Dysponując danymi ze wszystkich uczelni w Polsce można by (i z pewnością warto by było) przeprowadzić analogiczne analizy dla innych uczelni, a przede wszystkim - analizując zachowania absolwentów na podstawie zaprezentowanego schematu decyzyjnego - obserwować skalę i trendy dotyczące mobilności międzyuczelnianej.

\section{BIBLIOGRAFIA}

Baczko-Dombi A., Żółtak T., Edukacja, [w:] Współczesne społeczeństwo polskie. Podręcznik akademicki, red. A. Giza, M. Sikorska, Wydawnictwo Naukowe PWN, Warszawa 2012.

Baczko-Dombi A., Komendant-Brodowska A., Teoria racjonalnego wyboru - integracja nauk społecznych. Zastosowanie diagramu Jamesa Colemana w analizie zjawisk społecznych, [w:] Podejścia badawcze i metodologiczne w nauce o polityce, red. P. Ścigaj, B. Krauz-Mozer, Księgarnia Akademicka, Kraków 2013.

Bożykowski M., Izdebski A., Jasiński M., Konieczna-Sałamatin J., Styczeń M., Zając T., Ścieżki edukacyjne i zawodowe absolwentów Uniwersytetu Warszawskiego, Edukacja, 2014, 3(128).

Breen R., Goldthorpe J.H., Wyjaśnianie zróżnicowań edukacyjnych: w kierunku formalnej teorii racjonalnego dziatania, [w:] O socjologii. Integracja badań $i$ teorii, red. J. Goldthorpe, Wydawnictwo IFiS PAN, Warszawa 2012 [zmodyfikowana wersja artykułu: R. Breen, J.H. Goldthorpe, Explaining educational differentials: towards a formal rational choice theory, Rationality and Society, 1997, 9, s. 275-305].

Coleman J.S., Social theory, social research, and a theory of action, American Journal of Sociology, 1986, 91, 6 .

GUS, Szkoty wyższe i ich finanse w 2013 roku, Warszawa 2014.

Haman J., Gry wokót nas. Socjolog i teoria gier, Wydawnictwo Naukowe Scholar, Warszawa 2014.

Herbst M., Sobotka A., Mobilność społeczna i przestrzenna w kontekście wyborów edukacyjnych. Raport $z$ badania, Instytut Badań Edukacyjnych, Warszawa 2014. 
IBE, Raport o stanie edukacji 2012. Licza się efekty, Instytut Badań Edukacyjnych, Warszawa 2012.

Izdebski A., Jasiński M., Zając T., Konieczna-Sałamatin J., Ogólnouniwersytecka Ankieta Oceniająca Jakość Ksztatcenia. IV edycja. Raport z badania, Uniwersytet Warszawski, Warszawa 2012.

Jasiński M. i in. Ogólnouniwersytecka ankieta oceniająca jakość kształcenia. Trzecia edycja. Raport, Uniwersytet Warszawski, Warszawa 2010.

Jasiński M., Bożykowski M., Zając T., Styczeń M., Izdebski A., Dokładniej, rzetelniej, taniej. Badania oparte na rejestrach publicznych jako szansa dla badań spotecznych $w$ Polsce, Studia Socjologiczne, 2015, 1(216).

Komendant-Brodowska A., Baczko-Dombi A., Lokalne uwarunkowania decyzji edukacyjnych $w$ perspektywie teorii racjonalnego wyboru. Koncepcja teoretyczno-metodologiczna, Analizy IBE, 2015, 4.

Lalman D., Oppenheimer J., Świstak P., Formalna teoria wyboru racjonalnego. Kumulatywne nauki polityczne, Studia Socjologiczne, 1994, 3-4(134-135).

Lissowski G., Teoria racjonalnego wyboru, [w:] Encyklopedia socjologii, Wydanie 4, Oficyna Naukowa, Warszawa 2002.

Lissowski G., Zasady sprawiedliwego podziału dóbr, Wydawnictwo Naukowe Scholar, Warszawa 2008.

OECD, Education at a Glance: OECD Indicators, OECD Publishing, 2014.

Reichert S., Tauch C., Trends 2003. Progress towards the European Higher Education Area, http://www.eua.be/eua/jsp/en/upload/Trends2003final.1065011164859.pdf [dostęp: 10.09.2012].

Wallgren A., Britt W., Register-based Statistics. Administrative Data for Statistical Purposes, John Wiley \& Sons, West Sussex 2007.

Weiss A., Human capital vs. signalling explanations of wages, The Journal of Economic Perspectives, 1995, 9, 4 .

Zając T., Jak kandydaci staraja się dostać na studia? Analiza strategii kandydatów na wybrane kierunki studiów na Uniwersytecie Warszawskim, Decyzje, 2011, 16. 